J. of Modern African Studies, 56, 2 (2018), pp. 189-216 C Cambridge University Press 2018. This is an Open Access article, distributed under the terms of the Creative Commons Attribution licence (http://creativecommons.org/licenses/by/4.o/), which permits unrestricted re-use, distribution, and reproduction in any medium, provided the original work is properly cited.

doi:10.1017/SoO22278X18000198

\title{
Shifting visions of property under competing political regimes: changing uses of Côte d'Ivoire's 1998 Land Law*
}

\author{
Catherine Boone \\ Departments of International Development and Government, London \\ School of Economics and Political Science, Houghton Street, London \\ $W_{2} A$ 2AE, United Kingdom \\ Email: c.boone@lse.ac.uk
}

A B S T R A C T

Land law reform through registration and titling is often viewed as a technocratic, good-governance step toward building market economies and depoliticising land transactions. In actual practice, however, land registration and titling programmes can be highly partisan, bitterly contentious, and carried forward by political logics that diverge strongly from the market-enhancing vision. This paper uses evidence from Côte d'Ivoire to support and develop this claim. In Côte d'Ivoire after 1990, multiple, opposing political logics drove land law reform as it was pursued by successive governments representing rival coalitions of the national electorate. Between the mid-199os and 2016, different logics - alternatively privileging user rights, the ethnic land rights of autochthones, and finally a state-building logic-prevailed in succession as national government crafted and then sought to implement the new 1998 land law. The case underscores the extent to which deeply political questions are implicated in land registration and titling policies.

* The author thanks LSE STICERD for pilot project research funding in 2015 and 2016, colleagues for support and assistance in Abidjan, and J-P. Colin, Alice Sindzingre, James Putzel and anonymous JMAS reviewers who provided comments on earlier drafts. Earlier versions were presented in seminars at the University Alassane Ouattara of Bouaké, hosted by Prof. Francis Akindès (11 Sept. 2015), and the LSE Land, Institutions, Conflict Workshop (28 April 2017). I thank participants in these seminars for their comments. Thanks also to the LSE ESRC-funded CPAID project (ES/Poo8o38/1) for support during revisions. All mistakes are my own. 
Land law reform via registration and titling continues to be viewed by many as a technocratic, good-governance step toward building liberal market economies and depoliticising land transactions. In actual implementation, however, land registration and titling programmes have often been driven by very different priorities and dynamics. In the African countries of Côte d'Ivoire, Kenya, South Sudan, Uganda and others, recent land law reforms that promote formalisation of land rights have been used in partisan, starkly redistributive, and sometimes politically explosive ways. In these settings, land law reforms have often been as much about extending and consolidating political power as they are about limiting the state and freeing markets. In some situations, they have been as much an amplifier of social conflict as a solution to it.

Léonard et al. (2013: 10) argued that in the domain of land policy reform in Africa, political logics and control strategies often determine the course of change. This paper extends their argument, using the case of Côte d'Ivoire to show how regime change at the national level produced dramatic national-level shifts in the content, political purposes, and political uses of land law. Different logics - alternatively privileging user rights, the ethnic land rights of autochthones, and finally a statebuilding logic - prevailed in succession from the mid-1990s to 2016 . Even with a new land law in 1998 that aimed at land certification and titling, the politics around national strategies of implementation were at odds with liberal visions of market-building and individualisation.

In Côte d'Ivoire from the mid-1990s to 2016 , each change in the locus of political (partisan) control at the national level produced reversals in the thrust of land policy. Reversals were visible in the government's strategies to advance the land rights registration and titling agenda; in village delimitation and decentralisation strategies; and in legal adjudications of land law. This paper traces these shifts in national priorities, underscoring the deeply partisan thrust of land law reform in each era and in the larger state-building purposes that land law was harnessed to serve.

The analysis is organised chronologically. Part I is a brief overview of the pre-reform era, the 1960 os to the early 1990 , when land policy under the country's first president, Félix Houphouët-Boigny, was a 'land-to-thetiller' (or user-rights affirming) policy that was designed to promote land-pioneering in the zone of the rapid expansion of export-crop 
production. Houphouët's death in 1993 set in motion a reconsideration of Ivoirian land policy.

Part II centres on mid-199os pilot projects aimed at promoting the eventual registration (and perhaps titling) of landholdings. These took place amidst the national-level power struggles of 1993-2000. Power struggles found expression in a new land law, Law $98-75^{\circ}$, which contained an array of potentially or inherently conflicting provisions for assigning land ownership rights on the basis of autochthony (i.e. by confirming customary land ownership claims), and then dissolving these away under a World Bank-inspired individualisation and titling plan. Opposition leader Laurent Gbagbo, with an electoral base in the Ivoirian centre-west, was the leading national champion of the autochthony-affirming provisions of Law $98-75^{\circ}$.

Part III tracks the efforts of the regime of Laurent Gbagbo, who came to power in 2000, to realise the autochthony-affirming promise of Law 98-75 . Land activism under the Gbagbo government was aimed explicitly at replacing the Houphouëtist land regime with a land regime that asserted autochthonous communities' land ownership rights over those of migrants. The empowerment of autochthonous communities was to be confirmed through a sweeping political and administrative decentralisation.

Part IV shows that after the fall of the Gbagbo regime in 2011 , his successor, Alassane Ouattara, turned the tables once again in the land domain. The Ouattara government, with a power base in the Ivoirian north and among the northern diaspora of migrants in the southern Côte d'Ivoire, neutralised the anti-migrant thrust of the land law. In its first term (2011-2015), Ouattara's government used the provisions of the 1998 land law to promote the recentralisation of power, and to extend and deepen the state's presence in war-torn localities along Côte d'Ivoire's turbulent borders in the far western regions of the country. In 2011-2016, the government opened the doors to demand-driven registration and titling of land in a $5^{\mathrm{o}-\text { mile }}$ radius around Abidjan, but did not invest political capital in pursuit of the land privatisation agenda.

The paper contributes to knowledge about land politics in general and Côte d'Ivoire in particular by offering a national-level, political analysis of land policy since 2000. It fills a gap between two different literatures on Côte d'Ivoire since 2000, one on politics and the other on land use. Political analysis in the 2000 s focused mostly on the national crise socio-politique that brought Gbagbo to power, crystallised in a 2002 rebellion, divided the country into a government-controlled south and 
rebel-controlled north for five years (in a situation of 'neither peace nor war'), and culminated in disputed elections in 2010 and Gbagbo's removal from power by rebel forces aided by the international community in 2011. ${ }^{1}$ The fundamental role of land issues and of the 1998 land law in precipitating the crisis is a prominent theme in these studies. Yet there has been very little scholarly analysis of the Gbagbo government's efforts to actually deliver on the promise of Law $98-75^{\circ}$ in the government-controlled south in the 2000-2010 period, or political analyses of land policy under Ouattara during his first term in office (2011-2015). Indeed, much political science commentary conveys the impression that the 1998 land law and its political promises were swept away in the chaos of the crisis and war years. A separate stream of research on post-200o Côte d'Ivoire focuses on micro-level changes in land use and land contracting in the Ivorian south. ${ }^{2}$ This work tracks bottom-up drivers of change in the export-crop producing smallholder sector. It treats the 1998 land law as mostly non-implemented in the 1998-2015 period, with the important exception of the sharp uptake in land titling opportunities by members of the national urban elite in the region around the capital city of Abidjan. 3

The analysis here begins to fill these gaps. It draws upon local news reports, grey and secondary literature, Ministry of Agriculture internal documents from 2004-2006 and 2012-2015 that were consulted in Abidjan by the author. The record of land policy activism and its links to reforms of local governance structure during this period have not yet been described or analysed in the scholarly literature on Côte d'Ivoire. Approximately 25 unrecorded semi-structured interviews with actors in the Ivoirian land administration sector in 2015 and 2016 (in Abidjan and Bouaké) provided background information to supplement the document-based analysis.

The Ivoirian experience is significant for understanding contemporary land law reform in African countries (Boone 2007). It shows how land law reform initiatives aimed at land registration and titling can have domestic political drivers and effects that are only partially or even tangentially related to liberal visions of land privatisation, commodification and market-making. At the same time, it is a strong corrective to political science analyses that insist that partisan competition for state power in African countries is about ethnicity and patronage only, and void of real, programmatic stakes. In Côte d'Ivoire the opposite is the case: struggles over land law have been intertwined with partisan conflicts, electoral struggles, and actual battles over the national trajectory writ large. 
In the pre-reform era, from 1960 s to the early 1990 , land policy under Félix Houphouët-Boigny was designed to promote land-pioneering in the region of rapid expansion of export-crop production in the country's centre-west and south-western forest zones. Above all, it enforced user rights in this zone (i.e. upholding the rights of whoever was using the land, even if the users had no ancestral claims to it). In doing so, land policy promoted the land pioneering interests of the ethnoregional groups who were represented by the Houphouët regime, i.e. the Baoule of central Côte d'Ivoire and the northerners with whom they were allied within the ruling Parti Democratique de Côte d'Ivoire (PDCI). Baoulé and northern farmers and farmer-traders vigorously colonised the south-west forest zone with active state support and backing. To achieve this, Houphouët built a strongly authoritarian and centralised state which repressed indigenous groups (and their customary land claims) in the south-west. A voluminous literature documents and analyses this process. 4

II. LAND LAW INNOVATION AND REFORM IN THE $199 \mathrm{OS}$

Côte d'Ivoire was one of four francophone West African countries to begin implementing a Plan Foncier Rural (PFR) project in the late 1980s. With active support from the World Bank and the French Cooperation, the PFR envisioned a process of definition of village territories and lands (terroirs villageois), registration of land rights, creation of the institutional framework necessary for the eventual conversion of customary rights into statutory land rights, and land use planning at the village level.5 In western Côte d'Ivoire, land pressure was mounting, along with political tensions between autochthones and in-migrants over land rights. The general economic conjuncture contributed to rising social and political tension around land. The mid-198os were a time of economic recession, shrinking employment and IFI-imposed austerity which choked off growth of the cities and sent the middle class into a tailspin. In response to recession and fiscal austerity, unemployed urban youth began to 'return to the land', but many who returned to the western regions found that in-migrants now occupied most of their families' land. One proximate goal of the PFR in the west, as least as far as the Ivoirian Ministry of Agriculture was concerned, was to release some of this pressure by identifying underutilised tracts of land that could be made available to unemployed youth. Around Soubré 
in the south-west, plans to build a new dam on the Sassandra River created a separate need to survey local populations and landholdings which dovetailed with some of the proximate objectives of the PFR.

Between 1989 and the end of 1995, the larger political context also shifted. Côte d'Ivoire returned to multipartyism in 1991, and in 1993, Houphouët died and power passed to his hand-picked successor, Henry Konan Bédié. During this period, the PFR progressed in five pilot zones. About 425 , ooo ha of village land was mapped, with village boundaries and existing land rights traced out on the basis of local interviews: Béoumi (110,ooo ha), Korhogo (192,000 ha), Abengourou (58,ooo ha), Soubré (33,ooo ha) and Daloa (32,0oo ha) (Chauveau et al. 1998: 577). In January 1997, the PFR matured into the Programme National de Gestion des Terres Rurales (PNGTER), with a wider mandate and a greater emphasis on individual titling per se (see Stamm 2000). ${ }^{6}$

The very process of 'village land surveys', the basic tool in the PFR toolkit, stoked tensions in the central and western parts of the Ivoirian forest zone. Surveys asked village elites and household heads to inventory their landholdings, and to specify who owned what, who had gained access to the land via whom, and who had rights to stay on or dispose of the land.7 This unfolded in the context of intensifying partisan competition and political polarisation at both the local and the national level. Conflict was especially acute in the centre-west and west, where politicians from the ruling PDCI and their newly unleashed partisan rivals, organised in the centre-west by Laurent Gbabgo under the banner of the Front Populaire Ivoirien (FPI), instrumentalised indigene-stranger tensions to mobilise rival electoral constituencies. The political, economic and social climate deteriorated. In the 1995 elections, as the PFR 'pilot' phase was coming to an end, 5 , ooo in-migrants (most of them Baoulé) were expelled by grassroots militia from the Gagnoa area in the Ivorian centre-west (Babo \& Droz 2008). A large scholarly literature analyses this difficult history. ${ }^{8}$

As land tensions and partisan struggle intensified, the World Bank pressured the Côte d'Ivoire government to move forward on a land policy aimed at registration and titling as part and parcel of 'second generation structural adjustment' reforms. Politicians and representatives from the regions most affected by land-related tensions (the centrewest, south-west and south-eastern coastal zone around Bonoua) became actively involved in formulating and 'sensibilising' populations around reform proposals, seeing promise and risk for themselves and their constituencies in the prospect of a major new land law. 
In December 1998, the ruling party, the PDCI, introduced a new land law that would largely supersede the PFR and the PNTGER.9 It aimed at titling and registration, and unleashed bitter controversy. In National Assembly debates, the ruling party was split by the proposal to confirm 'customary rights ceded to a third party' as property rights that could be registered and titled. PDCI delegates from the west joined the inflamed opposition party, Gbagbo's FPI, in protest. ${ }^{10}$ The FPI saw this clause as a green-light to those who would dispossess autochthonous westerners of their land rights. Suspension of National Assembly deliberations gave the FPI time to compose a counter-proposal that (a) inserted a nationality clause into the law (reserving the right of property ownership to Ivoirian nationals) and (b) vested the power to confirm the initial allocation of land ownership rights in autochthonous elders at the village level. This satisfied the FPI and other members of parliament from the west who had opposed the first version of the law, and were intent on ensuring that guardians of autochthones' interests would have a strong hand in determining how the new law was implemented at the local level. Some observers remember that some Ivorian legislators were very concerned to block or pre-empt large-scale sales or concessions to foreign (nonAfrican, corporate) investors. Meanwhile, the law received some support from deputies who wanted to create a path to registration and titling to facilitate private acquisition of land and investment in agriculture. ${ }^{11}$

Law $98-75^{\circ}$ is remembered as having passed unanimously, but if it did so, it passed in a very divided parliament. Some deputies apparently began to renounce it as soon as it was passed. One analyst reported that 'The Baoulé lobby opposed it' (Boni n.d.). If this is true, it is not surprising: the law dramatically weakened the position of in-migrants to the centre-west and south-west, be they Baoulé, Ivoirians from the north, or foreigners. Implementing decrees (décrets d'application) were promulgated on 13 October 1999 .

There was an upsurge in assertiveness of autochthones around land rights in the centre-west and far west. A dramatic expression was the November 1999 expulsion of Ivoirien northerners (Lobi) and Burkinabe from Tabou. ${ }^{12}$ This was followed by the military coup d'état of 24 December 1999, mounted by junior officers claiming to represent disaffected northerners. A new military regime under General Robert Guëi was installed. The violent expulsions of non-indigenes from the west and widespread social destabilisation set off by the passage of the new land law contributed indirectly to this outcome. Guëi was displaced by Gbagbo less than a year later in the flawed presidential election of October 2000. ${ }^{13}$ 
III. LAND POLICY UNDER THE GBAGBO REGIME: SCALES TIPPED DECISIVELY IN FAVOUR OF AUTOCHTHONES

The 1998 land law overturned a status quo in which the government enforced the principle that working the land (mise en valeur of the land) was the source/origin of land use rights. ${ }^{14}$ The new law was widely interpreted as mandating first registration of all unregistered rural land (approximately $98 \%$ of the national territory) in the name of autochthonous owners - this was to happen throughout the national territory within a period of 10 years. ${ }^{15}$ It reversed Houphouët's legacy of enforcing the primacy of user rights in the most dynamic zones of export-crop production in the centre-west, south-west and far west, and thus represented dramatic inversion of the rapports de force between in-migrants and autochthones in these regions. At the end of the 10-year registration period, all unregistered land was to become the property of the state.

Much commentary holds that Law $9^{8-} 75^{\circ}$ was not implemented or never implemented. ${ }^{16}$ This statement is true in a narrow sense: by 2008 , only a miniscule number of land certificates had been issued for rural landholdings. Implementation more broadly understood, however, entailed concerted activism on the part of the Gbagbo regime to prepare the ground for implementing the 1998 law, and to seize the possibilities for an autochthonous rights revival that the law seemed to authorise. Under Gbagbo, government policy aimed at transforming rapports de force between indigenes and migrants. Its thrust and intent were visible in three domains: (a) court cases; (b) the delimitation of village boundaries and the setting up of land rights-based political hierarchies within and among villages, and issuance of Certificats Fonciers (land certificates); and (c) efforts to pursue political and administrative decentralisation. Each is discussed below.

The scope of these efforts was limited in geographic and financial terms, largely due to the politico-military crisis of 2002-2006 and its aftermath, followed by the final defeat of the Gbagbo regime in 2011 . Even so, we see in these efforts a concerted attempt to use Law $9^{8-75^{\circ}}$ to affirm autochthonous land rights and embed these in a larger political and legal order that gave primacy to the local.

\section{Court cases}

As Dagrou (2007: 53-6, 112-13) recounts systematically, the autochthony-affirming content of Law $98-75^{\circ}$ was stridently asserted in a 
series of court cases between 2002 and 2006, notably from Daloa, a strongly pro-Gbagbo region. A June 2002 court case in Cour d'Appel de Daloa ruling reads that 'given the law $98-75^{\circ}$ holding that only les populations autochtones riveraines (in a locality) have use rights, we can deduce that such rights can never result from a simple mise en valeur, and above and beyond that, a non-Ivoirian foreigner who, under the terms of the law just cited, is not destined (n'a pas vocation) to become the owner of a parcel of rural land'. ${ }^{17}$ In 2002, the Tribunal de première instance at Abengourou ruled on the 'nullité absolue' of a sale contract that has not been notarised. The Cour Suprême followed up, issuing in December 2003 an Arrêt confirming that no customary landholder has the right to cede property rights to a third party, even if the sale is notarised, further closing the door on legal recognition of past sales to non-autochthones. The Daloa court specified in June 2004 that 'customary rights in no way proceed from the mise en valeur of the land'.

In April 2005, a Sassandra ruling, confirmed in Daloa, went to the Cour Suprême which ruled that mise en valeur confers no customary use right (much less property right), and that the true property holder in the disputed case is the one who exercises customary rights 'sur la parcelle de ses ancêtres par voie de succession, comme la consacre la loi n. 98-75o du 23 december 1998'. In June 2005 the Daloa court proceeded to nullify notarised land sales and expel occupants from litigated parcels. In April 2006 the very active Daloa court also ruled that informally documented sales (acte sous-seing privé, presumably what are called 'petits papiers' in the land literature) are 'absolument nulle'.

\section{Village boundaries, village hierarchies, and issuance of CFs}

In 2002, the PNGTER was extended for the 2002-2010 period. This programme, run by the Ministry of Agriculture and the prefectoral corps, took up the project of delimiting and demarcating village territories. Although Law $98-75^{\circ}$ did not lay out procedures for village delimitation, delimitation was a precondition for the formation of village land committees (CVGFR) with authority to assign land rights within territorially demarcated units. For the Gbagbo government, the stakes in village delimitation were three-fold: formalising and officialising the primacy of autochthonous land rights; creating official village hierarchies which gave primacy to state-recognised autochthonous villages; and giving state recognition to 'naturalised' village origins and boundaries. Village 
and landholding mapping methodology was adapted from the procedures developed in the 1990 os under the PFR ${ }^{18}$ Issuance of land certificates followed from this and was underway in Gbagbo's last four years in power.

The first part of this sub-section describes this procedure, and the second analyses the patterns that emerged.

\section{Gbagbo regime demarcation and registration procedure}

The point-of-departure in delimiting village territories was the existing structure of territorial administration, in which the 'village territory' is the lowest-level administrative jurisdiction. Its political and administrative centre is the state-recognised village (village propre, or village érigé [erected] by the government), and the lowest-ranking agent of the territorial administration (subordinate to the sous-préfet) is the chief of the officially recognised village. The village territories demarcated in the PNGTER exercise measured between 1,000 and 3,000 ha in size $(2$, ooo ha $=7.6$ square miles $)$ and typically contain multiple, hierarchically ranked settlements. The officially recognised village is the seat of power with the village territory, and other settlements, often referred to as campements (camps) in Ivoirian parlance, are politically and administratively subordinate to (rattaché à) it. Administrative ideology and protocol is based on the idea that village territories are customary, historical or natural political homelands of some set of original inhabitants. In zones of in-migration, the campements or villages rattachés are settlements created by non-autochthonous 'outsiders' who settle with the permission of the indigenous local land authorities and the administrative chief. The in-migrants create their own, separate settlements within the village territory, at a distance from the villages propres. A land ownership hierarchy is thus embedded in officially recognised village hierarchies.

One of the stakes in the PNGTER delimitation and registration exercises was recognising or reforming pre-existing village hierarchies in the project zones. A campement or village rattaché that is granted proper village status (érigé en village) is 'liberated' from its former overlords, now holds land autonomously in its own right, and has its own village territory. Conversely, to lose village status and to be demoted to the status of a village rattaché is to be subjected to the authority of another group, and to have land access only with the permission of those who do control land with the village territory.

In the PNTGER project zones under the Gbagbo government, the state-led process of village delimitation, hierarchisation and land certification pivoted on the pervasive and long-maintained 'political- 
administrative distinction between 'autochthones', on the one hand, and 'allochtones de nationalité ivoirienne' and 'allogènes non-ivoiriens', on the other hand' (Chauveau \& Colin 2014). The hierarchical structuring of villages and appointment of village chiefs was pre-decided, usually following the status quo but, as we shall see, not always. In advance of village surveys, sous-préfets organised the formation of Comités Villageois de Gestion de Foncier Rural (CVGFR, or Village Land Management Committees), presided over by the sous-préfets, who were to act as repositories of local knowledge about village histories, village boundaries, the allocation of customary land rights within village territories, and the granting of derived land rights to village outsiders. According to the PARFACI report (Varlet et al. 2014: 73), 90-100\% of the members of the CVGRF constituted in the 2006 exercise were autochthones, including members of the chefferies (see also Colin 2013:436). This is one indicator of the government's decision to throw its weight behind autochthones and a neocustomary vision of landownership.

With CVGFRs in place, an enquêteurappointed by the state was brought in to develop an official historique de la constitution du village using a 16item questionnaire, working in the presence of the CVGFR and other knowledgeable persons, and officialising the procès-verbal with the signatures of all CVGFR members. The next step entailed actually defining village boundaries, publicising the proposed boundaries in the village (and in neighbouring villages, the sous-préfecture office) to collect objections and endorsements, resolving disaccords, officialising village boundaries, placing boundary-markers and publishing an official map of the village limits.

Issuance of Certificats Fonciers and Certificats Fonciers Collectifs (CFCs) was to follow. CFCs were envisioned as instruments that would document extended family holdings, but would have a lifespan of only 3 years. Then the land would have to be divided up and registered and titled as individual private property.

The four project zones covered in 2006, totalling approximately $15^{\circ}$ villages, were in Abengourou, Daloa, Bonoua/Alépé and Soubré (see Figure 1).

\section{Analysis of Gbagbo regime delimitation and registration}

Table I compares and contrasts the four zones. What does this information reveal about the government's choice of pilot zones, and about the political or partisan logic, if any, that guided demarcation and land registration? 


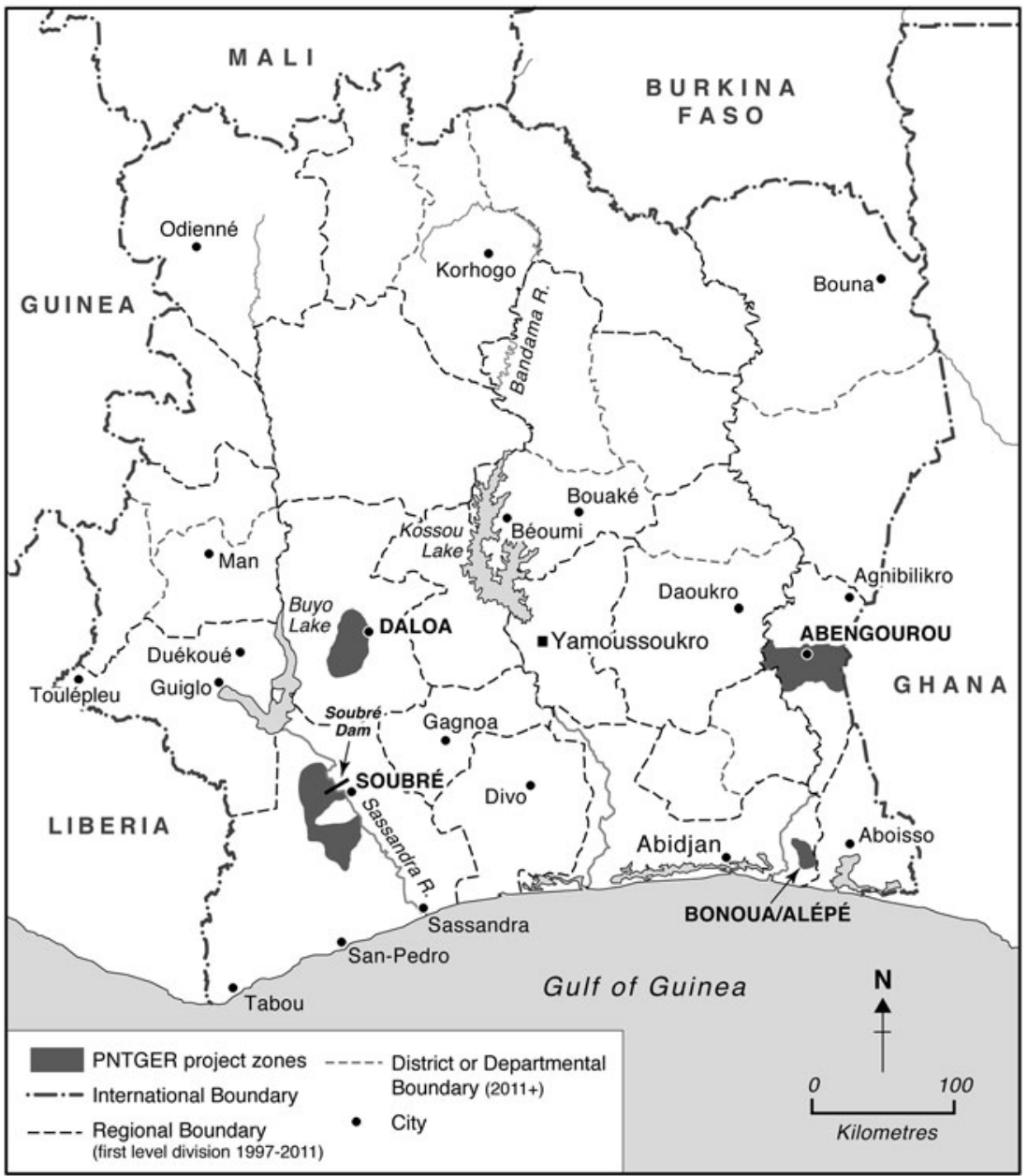

Figure 1 Map of the four zones of PNGTER village demarcation. Source: Map redrawn by Mina Moshkeri from Republique Côte d'Ivoire, Direction Foncier Rural, <www.foncierural.ci>, 15.11.2015.

The project areas were all politically accessible areas in southern Côte d'Ivoire (given the absence of the government in the north due to the political-military crisis) in which the FPI had either partisan control or a political foothold in a pro-FPI minority. The last column of Table I shows that two of the targeted zones, Bonoua/Alepe and Daloa, were areas of high partisan support for the FPI. Abengourou split its vote in 2000 between the PDCI and the FPI, but voted for the FPI in 2010. Soubré was a PDCI stronghold. Here, the PNTGER project built upon 
TABLE I

Comparison of $2005^{-2006}$ village delimitation cases

\begin{tabular}{|c|c|c|c|c|c|c|c|c|}
\hline Regions & $\begin{array}{l}\text { 'villages } \\
\text { propres' } \\
\text { delimited } \\
2005^{-6} \text { (no.) }\end{array}$ & $\begin{array}{l}\text { no. of villages } \\
\text { rattachés } \\
\text { named; no. of } \\
\text { campements }\end{array}$ & $\begin{array}{l}\text { Timing } \\
\text { of in- } \\
\text { migrant } \\
\text { influx }\end{array}$ & $\begin{array}{l}\text { In-migrants, } \% \\
\text { total } \\
\text { population* }\end{array}$ & $\begin{array}{l}\text { Source of migrants' } \\
\text { derived land rights }\end{array}$ & $\begin{array}{l}\text { Level of land } \\
\text { rights } \\
\text { contestation } \\
\text { c. } 1990\end{array}$ & $\begin{array}{l}\text { Village hierarchy } \\
\text { of } 199 \text { os } \\
\text { confirmed? }\end{array}$ & $\begin{array}{l}\text { Department- } \\
\text { level electoral } \\
\text { wins (by party) } * *\end{array}$ \\
\hline $\begin{array}{l}\text { Abengourou. } \\
3 \text { sous- } \\
\text { préfectures }\end{array}$ & 25 & $\begin{array}{l}6 \text { villages } \\
\text { rattachés, } 211 \\
\text { camps. } \\
25 \% \text { of total } \\
\text { are rattachés }\end{array}$ & $\begin{array}{l}1920 \text { - } \\
1940 s\end{array}$ & $40 \%$ & $\begin{array}{l}\text { chiefly hierarchy; } \\
\text { uncontested sales; } \\
\text { tenancy and wage } \\
\text { labour relations }\end{array}$ & very low & accentuated & $\begin{array}{l}\text { PDCI (2000 } \\
\text { leg.), FPI ( } 2000 \\
\text { pres., } 2010 \\
\text { pres.) }\end{array}$ \\
\hline $\begin{array}{l}\text { Bonoua/ } \\
\text { Alépé } \\
2 \text { sous- } \\
\text { préfectures }\end{array}$ & 4 & $\begin{array}{l}2 \text { villages } \\
\text { rattachés, } 13 \\
\text { camps. } \\
50 \% \text { are } \\
\text { rattachés }\end{array}$ & $\begin{array}{l}1900 \text {, } \\
195^{\text {OS- }} \\
1960 s\end{array}$ & over $40 \%$ & $\begin{array}{l}\text { self-settled } \\
\text { w/ government's post- } \\
\text { hoc ratification in } \\
1980 \text { s }\end{array}$ & medium & $\begin{array}{l}\text { confirmed (auton- } \\
\text { omy of some in- } \\
\text { migrant villages is } \\
\text { confirmed) }\end{array}$ & $\begin{array}{l}\text { FPI }(2000, \\
2010)\end{array}$ \\
\hline $\begin{array}{l}\text { Daloa } \\
1 \text { sous- } \\
\text { préfecture }\end{array}$ & 39 & $\begin{array}{l}\text { o villages } \\
\text { rattachés, over } \\
222 \text { camps. }\end{array}$ & $\begin{array}{l}1960 s \\
\text { and } \\
197 \text { os }\end{array}$ & $30-40 \%$ & $\begin{array}{l}\text { lineage heads and state } \\
\text { agents, weak tutorat } \\
\text { relations }\end{array}$ & very high & accentuated & $\begin{array}{l}\text { FPI (2000, } \\
2010)\end{array}$ \\
\hline $\begin{array}{l}\text { Soubré } \\
1 \text { sous- } \\
\text { préfecture }\end{array}$ & 5 & $\begin{array}{l}24 \text { villages } \\
\text { rattachés, over } \\
375 \text { camps. } \\
80 \% \text { of total } \\
\text { are rattachés }\end{array}$ & $\begin{array}{l}1970 s, \\
1980 s\end{array}$ & $80 \%$ & $\begin{array}{l}\text { state agents, } \\
\text { w/ village chiefs' } \\
\text { consent; weak tutorat } \\
\text { relations from } 1980 \text { s } \\
\text { which had fallen into } \\
\text { disuse }\end{array}$ & very high & $\begin{array}{l}\text { inverted: existing } \\
\text { village auton- } \\
\text { omies overturned }\end{array}$ & $\begin{array}{l}\text { PDCI (2000, } \\
2010)\end{array}$ \\
\hline $\begin{array}{l}\text { Total } \\
7 \text { sous- } \\
\text { préfectures }\end{array}$ & 73 & $\begin{array}{l}32 \text { villages } \\
\text { rattachés } \\
\text { over } 602 \\
\text { camps. }\end{array}$ & & & & & & \\
\hline
\end{tabular}

* First three rows from Bouquet (201 1: 201). ** By departmental results for 10 Dec. 20oo legislatives, 200o presidential, and presidential (2nd round) of 31 Oct. 2010, Bouquet (2011: 65 $73,15^{8)}$, Bassett (2011: 475). Source: Author's notes from village demarcation project collection; see also notes in Table. 
the support base of a local pro-FPI autochthonous minority. Three of the four were PFR project zones, so groundwork for village delimitation and land adjudication had already been laid. Northern departments were absent from the list: the Gbagbo government could not access the rebel-controlled North until after 2006; it was a region hostile to the FPI and was also a region in which there was resistance to land certification. ${ }^{19}$

The project zones were heterogeneous in terms of critical settlement history variables: the timing of in-migration, demographic balance between ethnic insiders and outsiders, and level of contestation over land rights, as summarised in Table I. In general, timing of in-migration is earlier in the east, having taken place in the colonial period, than it is in the west. In the west, the migratory in-flows were more recent - they happened in the post-colonial period - and the demographic weight of the in-migrants (ethnic outsiders) is higher. Levels of contestation over land rights were also much higher in the west than they were in the east (as discussed above). ${ }^{20}$

A review of approximately half of the 150 village dossiers prepared by PNTGER in 2005-6 offers evidence of the government's commitment to give pouvoir décisif aux autochtones in the Abengourou, Soubré and Daloa project zones. ${ }^{21}$ In Bonoua/Alépé, the land-use rights of long-settled inmigrants were shored up. The village enquêtes confirm the heavy insistence on documenting first-comer rights, and confirming their primacy through the public process of documentation and recording (in writing) individuals' consent to the official record. Enquêtes clearly differentiated between land-owning villages and subordinate, non-owning villages (officialising status of 'village without land' or 'village installed within the territory of village $\mathrm{X}$ ' in Abengourou and Bonoua/Alépé, and of village rattaché in Daloa and Soubré). In 'landless villages' and villages rattachés, male household heads signed (or gave fingerprints) to foreswear any claim to customary land rights of ownership. This officialised hierarchical relationships among villages and among residents of the village territories.

It is remarkable that in Soubré, this effect was achieved through inversion of the prevailing administrative status quo. In-migrants' status was demoted in order to elevate the autochthones. Administratively recognised, autonomous villages established in the 1980s, mostly Baoulé, were demoted to the status of campements subordinated to officially recognised Bakwé villages. One marker of the in-migrants' reversal-offortune was the renaming of villages: Baoulé or northern-sounding village names replaced by Bakwé names. 
Because enquêtes historiques of villages were aimed at establishing autochthony or first-comer rights, settlement history was critical. Each village dossier contains answers to the 16 questions that made up the village history survey. Recorded answers are short and tend toward the formulaic. The official village histories locate the origins of almost all of the autochthonous villages deep in the pre-colonial period - going back to the 1600 , 1700 or 1800 s. Histories include accounts of relocations, especially for villages in the west (which are attributed to the search for better sites) and the date at which the settlement was érigé en village (i.e. officially granted 'village' status) by the colonial or Ivoirian administration. ${ }^{22}$ Village histories record non-political and naturalised accounts of village limits, referring to a river, creek, bas-fonds, or the long history of entretien des pistes, roads or boundaries between villages. Mentions of disputes, boundary changes, administrative divisions, etc. do not appear. Agreement on village boundaries through this process was followed by investment in actually demarcating the villages. Approximately 5, ooo geocoded bornes were set in place under the Gbagbo regime. ${ }^{23}$

Official village histories tell the story of the land rights that the Gbagbo government sought to affirm in its implementation of Law

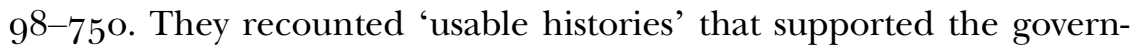

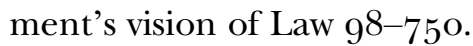

In December 2007, a new Programme National de Sécurisation Foncier Rural (PNSFR) was launched to spearhead an ambitious expansion of the village delimitation and land registration programme, with World Bank and EU funding. It elaborated a plan for mass communication and sensibilisation about Law $9^{8-75^{\circ}}$. In 2009, Desiré Zalo, then Director of the Direction du Foncier Rural (DFR), reported at an Abidjan conference that $15^{\circ}$ villages (out of a total of 11 ,ooo in Côte d'Ivoire) had been delimited so far, that 340 were in the process of delimitation, and that 400 were scheduled for delimitation in $2010 .{ }^{24}$

The final balance sheet for village delimitation and land certification under the Gbagbo government was as follows: approximately 170 village delimitations (covering 1.1 million hectares of territory) were completed, ${ }^{25}$ and $198 \mathrm{CFs}$ had been issued. ${ }^{26}$ Of these CFs, 135 (68\% of the total) were issued in Abengourou and Agnibilikrou, 19 in Soubré $(10 \%)$ and 18 in Daoukro (10\%). The remaining 25 CFs were scattered around the south. Only 4 CFs $(2 \%)$ were issued in Gbagbo's home region. ${ }^{27}$ Most of the certified parcels are small- to medium-sized by smallholder standards. Approximately $95 \%$ of the certified parcels in Abengourou and $75 \%$ of the parcels in Soubré were under 10 hectares. 
A few CFs for very large holdings were issued to political dignitaries in the West.

The Abengourou region, the only region in which more than a few CFs were issued, was surely the easiest place to certify parcel ownership, given the generally low levels of land tension, long and uncontroversial settlement histories (see Table I), relatively wealthy landholders by Ivoirian standards (Gastellu 1982, 1989), and the historically high levels of literacy and rural prosperity which characterise this region. ${ }^{28}$ Chauveau \& Colin (2014) commented that land certification was easiest and progressed furthest where it was least needed, either to mitigate conflict or promote land transactions. Daloa and Soubré make this point by way of counter-example: conflict levels were high and land certification stalled.

\section{Decentralisation under the Gbagbo regime}

The Gbagbo regime's land agenda was integrated into a broader vision of state restructuring that would promote localism, autochtonie and ethnic prerogative. The government undertook to remould chefferie law to create a chieftaincy hierarchy that would be comprised of already existing, first-level chefs de village (members of the CVGFR), complemented by second-level chefs de tribu, third-level chefs de canton and fourth-level chefs de province (at the departmental level). Gbagbo's Minister of the Interior, Désiré Tagro, undertook consultations 'with kings and traditional chiefs' to promote the official effort to 'bringing back the old structures' (remet en scène l'ancienne organisation).$^{29}$

An elaborate plan for reorganising territorial administration furthered this vision of restoring local prerogative and valorising communal initiative. In 1997, a 'strategy for decentralisation and development (aménagement) of the national territory' had been adopted by the Côte d'Ivoire Donors' Roundtable. It formalised the goal of total 'communalisation' of the country - i.e. conversion of all sous-préfectures to communes, so that each would have its own elected government. This idea lay dormant until 2001, when the Gbagbo government introduced a decentralisation strategy to be enacted through a series of laws and decrees in 2001, 2002, 2003, 2005 and 2008 that went even further than the 1997 proposals in enlarging and deepening the scope of decentralisation (Traoré 2010). A 2001 law (implemented in 2003) suppressed the old 'communautés rurales' and created new political jurisdictions - including villes, departments, districts and regions - and a new administrative 
hierarchy. As Traoré (2010: 9) describes it, this 'marked the massive creation of new communes and new departments ... In effect, by decree, the number of departments increased from $5^{6}$ to 80 and the number of communes in the country went from 198 to 1,008 , thus achieving the almost complete communalisation of the national territory.' Communes - some of them large villages - were given financial autonomy and a mandate to organise collective life, promote local development, modernise the countryside [le monde rural], and manage land and other local resources. $3^{\circ}$ This 'émittement territorial' (breaking up of the national territory into ever smaller units) was supposed to create 10 ,ooo jobs for new agents municipaux to be hired by local elected politicians (Traoré 2010: 2).

Possibilities for effective realisation of Gbagbo's vision of a new state architecture - one in which the local power-holders were strengthened, ethnic institutions were valorised, and resources and prerogative were devolved to the local level - were undermined by a broader crisis of state and economy after 2003.31 ${ }^{1}$ Gbagbo lost the disputed October 2010 national elections to Ouattara. In April 2011 Gbagbo was finally dislodged from power through military action by the Ouattara-aligned Forces Nouvelles rebellion assisted by international action..$^{2}$

IV. LAN D POLITICS UNDER OUATTARA：TABLES T URNED

Under the Ouattara government, the tables were turned. Ouattara's election in 2010 and installation in office in April 2011 represented a clear victory for those defending the rights of in-migrants in southern Côte d'Ivoire, and clear renunciation of the autochthony-promoting vision of Gbagbo and the FPI.33 The new government acted decisively to recentralise state power and to use possibilities inherent in the 1998 land law to achieve a new set of objectives.

Chauveau \& Colin (2014) describe a brief initial impulse on the part of the Ouattara government to discard the 1998 land law, or to revise it completely. In 2013, the government announced that Law 98-750 still stood, but with two reforms. 34 One prolonged the period of application of Law $98-75^{\circ}$ to 2023 . The second revised the nationality code to make naturalisation easier. The FPI (absent from the legislature due to a boycott of legislative elections) and elements of its strong regional constituency in the west protested the nationality law in strongest terms. Laurent Fologo, an FPI firebrand, excoriated the Ouattara government 
for undertaking to 'by the wave of a magic wand [through naturalisation law], expropriate the land of Ivioriens'.35

Implementation of the 1998 land tenure law remained a priority of Ouattara's backers in the EU and World Bank, surely because they subscribed to the general consensus that land problems had played a key role in fomenting devastating civil conflict in Côte d'Ivoire, and because they saw registration and titling as clearing the way for largescale investment in agriculture. Chauveau \& Colin (2014: 11-12) criticised the donors for maintaining 'a naive faith in land titles' and seeing the land cadastre 'as the holy grail'. Donors pledged about $10 \%$ of the estimated cost of delimiting all of Côte d'Ivoire's 11 , ooo villages, setting up CVGFRs, and issuing the estimated 300,ooo CFs that would be necessary to complete the task. As part of this effort, the EUand World Bank-funded PRSFR was resurrected in 2011 as the Programme d'Appui à la Relance des Filières Agricoles de Côte d'Ivoire (PARFACI). This relance called for the improvement of the legal framework, training of actors involved in implementing the [land] law, securisation of village lands by delimitation of terroirs villageois, the creation of a digital cadastre (Système d'Information Foncière) $3^{6}$ and the relaunching of the implementation (mise en oeuvre) of the 1998 land law (Leroy et al. 2012).

Yet during Ouattara's first mandate (2011-2015), the Ivoirian government did not embrace these priorities. Ambitions for general land certification and private land titling were restrained. Much landrelated conflict still simmered in the rural areas. In the West, where 3,000 people were killed in land-related violence in 2010-2011, the flames of civil war had barely subsided. Land-related violence continued throughout 2012, 2013 and 2014. Activism to implement (or indeed, to revoke) Law $9^{8-} 75^{\circ}$ could have stirred up conflict that would be difficult to contain in southern Côte d'Ivoire. In northern Côte d'Ivoire, to promote Law $9^{8-} 75^{\circ}$ would have been to antagonise core loyalists. 37 The overriding objectives of the Ouattara government in 2011-2015 were to tamp down civil unrest, protect its partisans in the rural and urban areas, and maintain control over the national territory.

Under the first Ouattara government, the political possibilities inherent in Law $9^{8-} 75^{\text {O were }}$ used most concertedly to promote state-building objectives, rather than the donor's objectives of land titling and promotion of land markets. The government's priorities were visible in three domains. First, in the domain of land certification, the government developed the legal/bureaucratic machinery (disposatif legal) required to respond to individual demands for land certification and 
titling, rather than pushing for state-led titling (except in two local zones). Second, the main thrust of the village delimitation process was redefined. Under Gbagbo, the process had been led by PNTGER and the Ministry of Agriculture, and was aimed at allocating and securing autochthones' land rights. Under Ouattara it was placed under the control of the Ministry of the Interior and harnessed to the 'redeployment of the state' and rebuilding of the territorial administration in war-torn western Côte d'Ivoire. $3^{8}$ Third, in the domain of decentralisation, Gbagbo strove to create a decentralised system anchored at the grassroots in local autochthonous communities and CVGFRs. The Ouattara government undertook a decisive recentralisation of authority.

\section{Land certification, $2011-2015$}

\section{Demand-driven certification}

Throughout almost all of the national territory, the Ouattara regime adopted a laissez-faire approach to land certification, waiting for demands for land registration to percolate up from commercially minded actors and investors. Demand-driven land certification was highly localised and concentrated in zones of new inward investment. Large-scale investors pushed some land certification. Foreign corporate investors covered the costs of issuing Certificats Fonciers Collectifs (CFCs) to a few villages adjacent to land concessions destined for palm oil and sugar plantations, in order to clarify boundaries. In Aboisso, the Ministry of Agriculture promoted the certification of outgrowers' plantations on palm oil schemes (with costs of the CF deducted from producers' income by the millers). 39 There was a similar case in Tabou. Yet the main drivers on the demand-side were what Tarrouth \& Colin (2016) call cadres acquéreurs, or the acquiring salaried class or more generally, the national urban elite. Of a total of 720 CFs covering a total of 41,5 oo hectares issued between 2011 and April $20154^{40} 400$ (47\%), accounting for a land area of 10,500 ha, were for parcels within an $80-100 \mathrm{~km}$ radius from Abidjan - in Agboville, Lagunes, Alépé. The average parcel size in Agboville was 28 ha. Much of the investment was going into the creation of hévéa (rubber) plantations.

\section{State-led certification}

State-led land certification continued in two local areas. Most was concentrated in EU- and WB-funded project zones in Abengourou and in 
the Soubré dam project zone. In Abengourou, an EU-funded registration project aimed at issuing 30,000 CFs in sous-prefectures delimited by PNTGER in 2006. By April 2015, 204 CFs had been issued in Abengourou and Agnibilekrou (with average parcel sizes of 9 and 47 ha, respectively), with costs of certification covered by the international donors. The Abidjan hinterland (the zone of demand-led certification) and Abengourou-Agnibilekou (the zone of state-led certification) accounted for over three-quarters of all CFs issued as of April 2015 .

There was a secondary zone of land-certification in the conflict epicentre around Duékoué in the Far West. The government's land certification project was financed by the African Development Bank (ADB). By April 2015 about 30 CFs had been issued in Duékoué and its surrounding villages. By September 2015 , about $15^{\circ}$ applications (dossiers) were in various stages of processing. ${ }^{11}$ The Duékoué projects were surely aimed at stabilisation and re-establishing order in this zone.

Critics of the government's slow process overall on the certification front argued that the lengthy (33 steps from the beginning of the certification process to the actual issuance of a land title) and costly registration process discouraged smallholders from seeking certification (Varlet et al. 2014: 36, 43). There was some urgency to the matter: under Law $9^{8-730}$ and its 2013 extension, land not certificated by 2023 will be considered 'sans maître' or ownerless and will become property of the state.

\section{Village delimitation in the far west}

During Ouattara's first mandate, the goal of using village delimitation to institutionalise the primacy of autochthonous land and political rights was dropped. Processes of village delimitation and land registration were disassociated. $4^{2}$ Under Ouattara from 2011-2015, security and state-building logics drove the agenda. Village delimitation was employed as a tool rebuilding the territorial administration in the wartorn West.

In 2013, a government ordinance specified procedures for delimiting village territories. 43 Shift from the term terroir to the term territoire signalled a shift away from the land-use and tenure concerns of the PFR and Gbagbo periods, and to a preoccupation with administrativeterritorial control. The Ministry of the Interior replaced the Ministry of Agriculture as the lead agency. With financing from the ADB, the government undertook village delimitation in the Far West. A large part of 
the effort was focused on the critical border-crossing sous-préfecture of Toulepleu, where 27 village territories were delimited during Ouattara's first mandate.

Village delimitation was accompanied by the appointment of village chiefs. An urgent priority was to empower local chiefs who could arbitrate on land conflicts (backed up by the prefectoral corps) between war refugees and those who had occupied the land in their absence. 44 Village demarcation and the appointment of chiefs were measures aimed at re-establishing order, securing 'local cohesion' and encouraging the return of the refugees. 45

\section{Recentralisation under Ouattara}

A September 2011 ordinance reorganising the territorial administration was followed in March 2012 by the suppression of 1126 communes, $4^{6}$ thus reversing Gbagbo's policy of communalisation totale. "[The government] believes that 1126 communes were created for political reasons and that they are not economically viable. The remaining 197 communes will stay.' 47 Villages were reattached to existing communes. Notre Voie, the FPI newspaper, reported bitterly that a Gbagbo regime 'policy that had been greeted enthusiastically by populations, offering them chance to 'take their own destiny in hand', had been 'killed in embryo ... Under Ouattara, Côte d'Ivoire has turned its back on decentralisation. ${ }^{\prime} 4^{8}$

Districts with their own governors, another product of Gbagbo's restructuring of the national political and administrative structure, were also eliminated. In a 2013 meeting with the prefectoral corps held at the presidential palace in Abidjan, Ouattara announced that he was not convinced that the district level of government was needed. The press announced 'the death of the districts'. 49 According to press reports, this was welcomed by the prefects who had viewed the district governors as compromising their mandate. $5^{\circ}$

A new chefferie law, passed in 2014, retained the four-tiered chiefly hierarchy in some regions, but not others. In Gagnoa, all of the hierarchical structure disappeared, leaving only the chefs de village. The Varlet report (Varlet et al. 2014: 54) explained that the goal of the government was to 'stabilise the chefferie'. Chiefs remain representatives of the state at the local level (village and canton), nominated by sous-préfets (sometimes after a local election), appointed officially by the Ministry of the Interior, and removable only with the permission of the administration. 
As for the village-level land committees, the CVGFR, the conventional wisdom in the administrative services responsible for land certification in 2015 was that these were not permanent local institutions. 'They will die along with the CFs' (i.e. when the CF is transformed into a land title).

Ouattara's first term in office ended in October 2015. During this time, the implementation of land policy served a state logic of extending territorial control more than the market-making logic envisioned by the IFIs, or the smallholder securisation logic that is of most concern to NGOs. A great deal of land conflict continued to simmer in the localities of Côte d'Ivoire, including conflicts between communities over 'autochthonous rights', between communities and the state, between investors and communities, and between autochthonous landholders and those claiming to hold ceded land rights. $5^{1}$

\section{O N C L U S I O N}

The adoption of a new land law in Côte d'Ivoire in 1998 has been interpreted as a decisive commitment to building a true land market. The argument here is that in fact, for the last two decades, the goals of freeing markets and facilitating transactions among market actors have often been tangential to the domestic political drivers and to the most immediate effects of reform. The Ivoirian case underscores the extent to which the politics of land titling and registration implicates, and is even defined by, political questions, rather than purely technocratic or narrowly market-focused ones.

Under Gbagbo and during Ouattara's first term in office, land law reforms, in both content and implementation, were instruments in larger political struggles for control of the national territory and the national trajectory. Land law reform revolved around questions of citizenship rights (autochthony vs. user rights), state structure (decentralisation and political status of the local community) and state sovereignty (state control over population and territory), rather than politically neutral market-making as imagined by some international promoters of land law reform. The Ivoirian experience is a useful point of reference for understanding land politics in cases such as Kenya and Uganda, where many of the same tensions and issues animate national and subnational struggles over land policy and land rights.

A counter-trend is visible across a zone of a radius of about $100 \mathrm{~km}$ from Abidjan, where registration and titling is driven by private investors 
who want to acquire land, mostly for hévéa plantations and mostly about 28 ha in size (as described above). Much of the land in this zone was extracted from the customary tenure domain in the $1930-1980$ period for the creation of foreign and state plantations..$^{52}$ Colin was describing this process when he observed that Law $9^{8}-75^{\circ}$ was accelerating processes of class formation in the agrarian sector 'through selective implementation of the law ... on a case-by-case basis in order to secure land transfers benefitting national elites (through purchase) or national or foreign agro-industrial firms (through long-term leases on certified and then titled land) (Colin 2013: 431). It does indeed square with the market-promoting vision embraced by the liberal promoters of land law reform. The question going forward is whether this will remain an enclave phenomenon, or whether it will diffuse into zones that are now under neo-customary forms of tenure. It remains possible that larger political-economic changes or land conflicts will swamp and subvert processes of privatisation and commodification.

A more immediate question has to do with the future of Law $98-75^{\circ}$ itself. Under current law, holdings not certified by 2023 become the property of the state. Many insiders in Côte d'Ivoire believe that this will never happen, that the law will be amended, and that the current provisions are only there to pressure smallholders to seek CFs. One could cite the disciplinary tone of the député (MP) in Divo, N'Guessan Denis, who told people in 2014 to 'immatriculate your lands before 2023, because if you don't, they will become the property of the state'.53

Under Ouattara's second term, which began in November 2015, government policy has been to accelerate the land certification process. Even so, it is possible that 2023 will arrive, and that the majority of small-scale landholders in Côte d'Ivoire will find themselves in the same legal position as in 1995, before the land law reform process began. Yet in contrast to 1995, the government's control over most land across the national territory will be extended, strengthened and more firmly rooted in law.54 State actors will be able to make longterm leases with investors throughout most of the national territory. In this situation, the security of most small-scale users' land rights will be determined by the political character of the regime in power, interactions between national and local actors and agendas, and the more general balance of state-society relations at the time. These larger political forces have gone far in determining the character of land law and policy to date. 


\section{NOTES}

1. For example, Chauveau (2000, 2002); Banegas \& Losch (2002); Bassett (2003); Akindès (2004); Marshall-Fratani (2006); Babo \& Droz (2008); Boone (2009); Bah (2010); Bouquet (2011); McGovern (2011) and Leroy et al. (2012). See also Crook (1990, 1997).

2. See Leroy et al. (2012); Colin (2013, 2017); Ruf (2013); Tarrouth \& Colin (2016); Colin \& Tarrouth $(2017)$.

3. Ibid.

4. See Dozon (1985) and note 1.

5. See Chauveau et al. (1998: $5^{80)}$; Stamm (2000); Lavigne Delville (2009).

6. Zalo (2006: 4) refers to a different time frame in offering a balance sheet. He describes the PFR (and the PNGTER, presumably) as rolled out in three phases in nine zones over the 19902002 period: 'Over the course of this period, 1,117,000 ha were delimited, 44,201 parcels were marked out (levées), and 708 villages were covered.'

7. See Chauveau et al. (1998).

8. See note 1.

9. Law $9^{8-75}$ o was not the direct or intended result of the PFR or PNGTER. Chauveau (2003: 2) explains that although the PFR had been seen as a step in the process of formulating new land legislation, (a) it did not include a plan to require formal registration of land certificates, and (b) it was still underway, having just scaled up from seven to nine project zones, in 1997. Even so, in 1999, the methodologies and procedures of the PFR and PNGTER were integrated into official procedures for land certification. This was formalised under Ouattara in decree no. 2013-296.

10. Stamm (2000) reported that the draft legislation contained a clause that would have revoked the user rights of those who could not prove that their land had been 'brought into use' (mise en valeur), but that this provision was withdrawn early on.

11. Some observers believe that some members of the national assembly were eager to acquire titles and invest.

12. See Babo \& Droz (2008).

13. Akindès (2004).

14. Chauveau \& Colin (2014: 6 inter alia). See Dagrou (2007: 112, n. 133).

15. In fact the law provided for the possibility that an Ivoirian could receive a certificate and title for land in a region in which he or she was a non-autochthone. Foreigners were not barred from receiving land certificates, but titles to this land are established in the name of the state (Chauveau 2000; Boone 2014).

16. Zalo (2006: 4); Dagrou (2007: 167); Colin (2013).

17. See also Boni (n.d.).

18. See Varlet et al. $(2014: 42,47)$. Law $98-75^{\circ}$ did not specify how village boundaries were to be delimited. So on this, the PNTGER programme operated in a vide juridique (juridical void) that was not filled until the Ouattara regime issued decree 2013-296. On the PFR process, see Colin $e t$ al. (2009); Lavigne Delville (2014).

19. Varlet et al. $(2014)$.

20. The extent to which the 'autochthony' was/is a bone of contention (i.e. the distinction between autochthone and first-comer, the question of who is autochthonous, and the matter of the land rights of autochthones versus in-migrants) varies across space and sometimes along other dimensions in Côte d'Ivoire, partly as a function of settlement history and variations in land tenure regime. See Boone (2014). See also Dozon (1985); Affou Yapi (1987); Gastellu (1989); Diaby (1996); Lesourd (2003); Colin et al. (2007); Babo (2010); Kouamé (2010); MacLean (2010).

21. The phrase in quotes is from Chauveau et al. (201 2: 29). About 75 PNTGER village dossiers were consulted in Abidjan in 2015 and 2016. The DFR holds a collection.

22. There is silence around the history of French wars of pacification and forced regrouping and resettlement of populations in the West. See Dozon (1985). Enqueteurs recorded the respondents' information about when the sites were érigé en village. Answers from Daloa included, for example, 'By the Commandant de Cercle in 1915', and in Soubré or Bonoua, 'By sous-préfet or préfet so-and-so in $1985 \ldots$...

23. Zalo (2006). Numbers averaged about $25^{-} 5^{\text {o }}$ per village territory.

24. Club Union Africaine Côte d'Ivoire (2009).

25. In November 2013, Minister of Agriculture Mamadou Sangafowa Coulibaly reported that 171 villages had been delimited and $30_{5} \mathrm{CFs}$ delivered (apparently out of 5 ooo requests/initiations of the process). 'Sangafowa Coulibaly: "La loi sur le foncier n'a pas été changée",' Frat.Info (Abidjan), 1 Nov. 
2013, <allafrica.com>, accessed 5.4.2015. Varlet et al. $(2014: 17,39)$ reported that 1,10o,ooo ha of village land was delimited in the 10 years of the PFR and PNGTER projects.

26. This is according to the Direction Foncier Rural tally consulted in April 2015 for the number of CFs issued by the end of 2010 . See also Club Union Africaine Côte d'Ivoire (2010).

27. That is, two in Lakota, two in Issia. The government was ready to issue CFs in Daloa in 2009 and 2010, where 44 villages had been enquêtés and 21 were bouclés, or completed. However this was aborted in October 2009 when the CVGFRs of the three targeted villages in Gboguhé souspréfecture all resigned en masse on the grounds that the 10 -year period of Law $98-75^{\circ}$ had expired and they feared that the state would use this as a pretext for expropriation of their land (Club Union Africaine Côte d'Ivoire 2009: 14, 19).

28. See also MacLean (2010).

29. Djé Abel, 'Chefferie traditionelle - Boga Joachim (chef de tribu): "J'ai de grandes ambitions pour ma tribu",' Notre Voie, 5 November 2014, < allafrica.com/stories/201411060997>, accessed 24.8 .2015 .

3o. Ahmed M. Troaré, 'Découpage Administrative - Entre politique et réalité de terrain,' NordSud (Abidjan), 15 December 2008, <fr.allafrica.com/stories/20081215557.html>, accessed 22.4 .2015 .

31. Ibid. This source reported that at a June 2008 seminar in Abidjan, delegates to a conference on local government complained that no money had been allocated to the local level, and that many new local units existed on paper only.

32. See Banegas \& Losch (2002); Bassett (2011); Straus (2011).

33. Ibid and note 1 .

34. 'Sangafowa Coulibaly: "La loi sur le foncier n'a pas été changée",' Frat.Info (Abidjan), 1 November 2013 , <allafrica.com>, accessed 5.4.2015.

35. 'Foncier rural - 'La loi expliquée à la presse', Notre Voie, 5 Nov. 2013 , <allafrica.com>, accessed 30.4.2015; and 'Lois sur la nationalité et de foncier rural - Fologo allume Ouattara', Notre Voie, 27 August 2013, <allafrica.com>, accessed 30.4.2015.

36. Varlet et al. (2014: 17).

37. On opposition to Law $98-75^{\circ}$ in the North, see Varlet et al. (2014: 105).

38. Decree $2013^{-296}$ of 2 May 2013 standardised the village delimitation procedure.

39. Especially the project 'Une parcelle d'hévéa, un certificat foncier', started in Sud Comoé (Aboisso) on 19 November 2014 by the Ministry of Agriculture. Costs of 180 ,ooo CFA per planter were to be deducted by the factory from the planter's earnings. With a land title, planters are supposed to be able to access bank credit.

40. This is of a total of $84^{1}$ issued since 1998. As of April 2015, certificats fonciers had also been issued for three large holdings in Bouaké, average size 1,200 ha each, and five large holdings (average size 273 ha) in San Pedro.

41. The April 2015 total for the West includes the five large holdings in San Pedro. Information about dossiers being processed in Duékoué is from the author's September 2015 interviews with land-sector actors in Abidjan.

42. An exception was Agboville where delimitation was to be resumed. The Agboville Prefect announced that campements would be elevated to village status. (@bidi@n.net, Abidjan.net, AIP, 'Region: L'opération de sensibilisation sur la délimitation des terroirs villageois lancée à Agboville,' 29 December 2013, accessed 2.4.2015).

43. That is, Law $2013^{-296}$ of 2 May 2013.

44. See Human Rights Watch (2013), Radio France Internationale, 'CI: Human Rights Watch alerte sur le risque de conflits fonciers,' 1o October 2013 (reposted in <allafrica.com>, accessed $5 \cdot 4 \cdot 2015)$.

45. Norweigan Refugee Council (2012); International Crisis Group (2014); Mitchell (2014).

46. Ordinance 2011-262 of 28 Sept. 2011 relative à l'organisation de l'administration territoriale created 31 regions and 108 departments. As of mid-2015 the regional level had not yet been funded.

47. Marcelline Boneton, 'Abengourou - Les populations déapprouvent la suppression de 1126 communes,' Notre Voie, 25 April 2012, <fr.allafrica.com/stories/201204251331.html>, accessed 17.5.2015. See also Dje Kim, 'CI: 1126 communes supprimées par le Gouvernement,' Le Nouveau Réveil (Abidjan), 8 March 2012, <allafrica.com/stories/201 203081124.html>, accessed 14.5.2015.

48. Guillaume T. Gbato, 'Suppression de plus de 1000 communes créées par Gbagbo', Notre Voie, 8 March $2012,<$ fr.allafrica.com/stories/201 203080396.html>. See Koffi et al. (2013). 
49. 'Décentralisation - Ouattara announce la mort des districts et s'en va au Nigeria et Togo,' Koaci.com, 13 September 2013 , <Koaci.com/cote-d'ivoire-decentralisation-announce-mort-districtsnigeria-togo- $85557 \cdot \mathrm{html}>$, accessed $15 \cdot 5 \cdot 2015$.

$5^{\text {o. Ibid. }}$

51. Varlet et al. $(2014: 101,110)$.

52. See Affou Yapi (1987).

53. Frat.Mat Info, 'Divo - les députés expliquent les lois votées aux populations du canton Abohiri

[Region Loh Djiboua, near Divo],'<AllAfrica.com>, 2014, accessed 5.4.2015.

54. This point is underscored in Alden Wily (2015).

\section{R E F E R E N C E S}

Affou Yapi, S. 1987. Les Planteurs Absentéistes de Côte d'Ivoire. ORSTOM Collection Travaux et Documents n. 210 . Paris: Editions de l'ORSTOM (Institute Français de Recherche Scientifique pour le Développement en Coopération).

Akindès, F. 2004. 'The roots of the military-political crises in Côte d'Ivoire'. Nordic Africa Institute Research Report no. 128 , Uppsala.

Alden Wily, L. 2015 . 'Vers une remise a plat? Bilan critique du droit foncier rural et forestier en Côte d'Ivoire'. UK \& Belgium: FERN (May). <www.fern.org>.

Babo, A. 2010. Les jeunes, la terre et les changements sociaux en pays baoulé (Côte d'Ivoire). Paris and Dakar: Editions Karthala, AfriMAP, et Le Centre de Recherches sur les Politiques Sociales (CREPOS).

Babo, A. \& Y. Droz. 20o8. 'Conflits fonciers, de l'éthnie à la nation: rapports interéthnique et 'ivoirité' dans le sud-ouest de la Côte d'Ivoire', Cahiers d'Etudes Africaines 48, 4: 741-63.

Bah, A. 2010. 'Democracy and civil war: citizenship and peace-making in Côte d'Ivoire', African Affairs 109: 597-615.

Banegas, R. \& B. Losch. 2002. 'Côte d'Ivoire au bord de l' implosion', Politique Africaine 87, Octobre: 139-61.

Bassett, T. 2003. "Nord Musulman et Sud Crétien': les moules médiatiques de la crise ivoirienne', Afrique Contemporaine 206, 2: $13^{-27}$.

Bassett, T. 2011 . 'Briefing: winning coalition, sore loser: Côte d'Ivoire's 2010 presidential elections', African Affairs 111: 469-79.

Boni, S. n.d. 'Comprendre l'esprit de la Loi n. 98-75o du 23 décembre 1998 portant Code Foncier rural en Côte d'Ivoire,' unpubl. ms., UFR de Sciences Juridiques, Administratives, et Politiques de l'Univ. FHB de Cocody, Abidjan, <https:// halshs.archives-ouvertes.fr/hal-o $111655^{\circ} /$ document $>$, accessed 10.4.2015.

Boone, C. 2007. 'Property and constitutional order: land tenure reform and the future of the African state', African Affairs 106: 557-86.

Boone, C. 2009. 'Electoral populism where property rights are weak: land politics in contemporary Sub-Saharan Africa', Comparative Politics 41, 2: 183-201.

Boone, C. 2014. Property and Political Order: Land Rights and the Structure of Conflict in Africa. Cambridge: Cambridge University Press.

Bouquet, C. 2011 . Côte d'Ivoire: Le désepoir de Kourouma. Paris: Armand Colin.

Chauveau, J.-P. 200o. 'Question foncière et construction nationale en Côte d'Ivoire', Politique Africaine 78: $94^{-125}$.

Chauveau, J.-P. 2002. 'Une lecture sociologique de la loi ivoirienne de 1998 sur le domaine foncier', IRD, Réfo. Doc. de Travail n. 6, Unité de Recherche o95, Sept. $4^{6}$ pp.

Chauveau, J.-P. 2003. 'Rural Land Plans: Establishing relevant systems for identifying and recording customary rights', IIED Issue Paper no. 122. London: International Institute for Environment and Development (IIED).

Chauveau, J.-P. \& J-P. Colin. 2014. 'La question foncière à l'épreuve de la reconstruction en Côte d'Ivoire: promouvoir la propriété privée ou stabliser la reconnaissance sociale des droits?', Les Cahiers du Pole Foncier, Pôle Foncier Montpellier 6: 6.

Chauveau, J.-P., P.-M. Bosc \& M. Pescay. 1998. 'Le Plan Foncier Rural en Côte d'Ivoire', in P. Lavigne Delville, ed. Quelles politiques foncières pour l'Afrique rurale? Réconcilier pratiques, légitimité et légalité. Paris: Karthala, 553-82.

Chauveau, J.-P., J.-P. Colin, S. Bobo, G. Kouamé, N. Kouassi \& M. Koné. 2012. 'Côte d'Ivorie: le foncier au coeur des enjeux de reconstruction', Grain de Sel 57 (janvier-mars): 28-30. 
Club Union Africaine Côte d'Ivoire. 2009. 'Programme de prévention des conflits fonciers et de consolidation d'une paix durable en milieu rural, financée par l'Union Européene: Rapport narratif intermédiare 2, (contract n. DDH/2006/123-232, for Jan. 2008-Mars 2009)', <www.clubua-ci. org $>$, accessed 6.11.2015.

Club Union Africaine Côte d'Ivoire. 2010. 'Rapport de la cérémonie de remise des premiers CF en Côte d'Ivoire [N=11 in Affalikro]', <www.clubua-ci-org $>$, accessed 6.11.2015.

Colin, J.-P. 2013. 'Securing rural land transactions in Africa: an Ivoiran perspective', Land Use Policy 13: $430-40$.

Colin, J.-P. 201 7. 'Contractual practice and land conflicts: the 'plant and share' arrangement in Côte d'Ivoire', Journal of Agrarian Change 1 7, 1: 144-65.

Colin, J.-P. \& G. Tarrouth. 2017. 'Les élites urbaines comme nouveau acteurs du marché foncier en Côte d'Ivoire', Géographie Economie Société 19, 3: 331-55.

Colin, J.-P., G. Kouamé \& D.M. Soro. 2007. 'Outside the autochthon-migrant configuration: access to land, land conflicts and inter-ethnic relationships in a former pioneer area of lower Côte d'Ivoire', Journal of Modern African Studies 45: 33-59.

Colin, J.-P., P.-Y. LeMeur \& E. Leonard, eds. 20o9. Les Politiques d'enregistrement des droits fonciers: du cadre légal aux pratiques locales. Paris: Karthala.

Crook, R. 1990. 'Politics, the cocoa crisis, and administration in Côte d'Ivoire', Journal of Modern African Studies 28, 4: 649-69.

Crook, R. 1997. 'Winning coalitions and ethno-regional politics: the failure of the opposition in the 1990 and 1995 Elections in Côte d'Ivoire', African Affairs 96: $215^{-42 .}$

Dagrou, T. 2007. Comprendre le Code Foncier Rural de la Côte d'Ivoire. Abidjan: Frat Mat Editions.

Diaby, N. 1996. 'Notables et paysans dans la forêt classée, un conflit d'environnement dans l'Est de la Côte d'Ivoire', in P. Mathieu, P.-J. Laurent \& J.-C. Willame, eds. Democratie, Enjeux Fonciers, et Pratiques Locales en Afrique. Bruxelles \& Paris: Institut Africain-CEDAF (Centre d'Etude et de Documentation Africaines) \& Editions L'Harmattan, 164-79.

Dozon, J-P. 1985. La Société Bété. Paris: Karthala.

Gastellu, J.M. 1982. 'Droit d'usage et propriété privée', in E. Le Bris, E. Le Roy \& F. Leimdorfer, eds. Enjeux Fonciers en Afrique Noire. Paris: Karthala: 269-80.

Gastellu, J.-M. 1989. Riches Paysans de Côte-d'Ivoire. Paris: L'Harmattan.

Human Rights Watch. 2013. 'Cette terre est la richesse de ma famille: Agir contre la dépossession de terres suite au conflit postélectorale en Côte d'Ivoire'. New York, NY: Human Rights Watch.

International Crisis Group. 2014. 'Côte d'Ivoire's Great West: Key to Reconciliation.' Africa Report no. 212 . Brussels: International Crisis Group.

Koffi, A., T. Gogbe \& M. Trotsky Mel. 2013. 'Décentralisation et crise économique en Côte d'Ivoire: Cas du Conseil Général de Dimbokro', European Scientific Journal 9, 25: 85-109.

Kouamé, G. 2010. 'Intra-family and socio-political dimensions of land markets and land conflicts: the case of the Abure, Côte d'Ivoire', Africa: Journal of the International African Institute 80, 1: 126-46.

Lavigne Delville, P. 2009. 'Conceptions des droits fonciers, récits de politiques publiques et controverses. Les Plans fonciers ruraux en Afrique de l'Ouest', in J.-P. Colin, P.Y. Le Meur \& E. Léonard, eds. Les politiques d'enregistrement des droits fonciers: Du cadre légal aux pratiques locales. Paris: Karthala: 69-104.

Lavigne Delville, Ph. 2014. 'Competing conceptions of customary land rights registration: rural land maps PFRs in Benin - Methodological, policy, and polity issues', IRD. HAL Archives Ouvertes, IRD-O 1113264 .

Léonard, E., J.-P. Chauveau \& P. Lavigne Delville. 2013. 'Introduction: Nouveau rapports de force et recompositions des régulations foncière en milieu rural', Terroires d'Afrique, 5: $3^{-10}$.

Leroy, M. L. N., A. Bankahla, J.-P. Chauveau, J.-P. Colin \& B. Losch. 2012. 'La loi foncière en Côte d'Ivoire', Foncier et Dévelopment, Comité Technique, Notes de Synthèse, n. $8<$ http://www.foncier-developpement.fr/wp-content/uploads/Notes-de-synthese_Numero8_Cote_Ivoire.pdf>.

Lesourd, M. 2003. 'Une remise en cause de l'ethnicité: Le comportement socio-spatiale des Baulé émigrés dans le sud-ouest de la Côte d'Ivoire', in J.-P. Chrétien \& G. Prunier, eds. Les Ethnies ont une histoire. Paris: Karthala: 77-9o.

MacLean, L.M. 201 o. Informal Institutions and Citizenship in Rural Africa: risk and reciprocity in Ghana and Côte d'Ivoire. Cambridge: Cambridge University Press.

Marshall-Fratani, R. 2006. 'The war of 'who is who': autochthony, nationalism, and citizenship in the Ivoirian crisis', African Studies Review 49, 2: 9-43.

McGovern, M. 2011. Making war in Côte d'Ivoire. Chicago, IL: University of Chicago Press. 
Mitchell, M.I. 2014. 'Land tenure reform and politics in post-conflict Côte d'Ivoire: a precarious peace in the western cocoa regions', Canadian Journal of African Studies 48, 2: 203-21.

Norwegian Refugee Council (NRC). 201 2. 'Land Conflict and Food Security in the Liberian-Ivoirian Border Region'. Oslo: Norwegian Refugee Council.

Ruf, F. 2013. 'Agriculture contractuelle et boom de l'hévéaculture villageoise en Côte d'Ivoire', Cahiers Agriculture 22, 1: $4^{6-} 5^{2}$.

Stamm, V. 200o. 'The Rural Land Plan: an innovative approach from Côte d'Ivoire'. Report 741722 and Drylands Issue Paper E91, <http://pubs.iied.org/741 7 IIED/?k=Cote+d\% 27 Ivoire >. London: International Institute for the Environment and Development (IIED).

Straus, S. 2011. "It's sheer horror here': patterns of violence during the first four months of Côte d'Ivoire's post-electoral crisis', African Affairs 110: 481-9.

Tarrouth, G.H. \& J.-P. Colin. 2016. 'Les acquisitions de terres rurales par les 'cadres' en Côte d'Ivoire: premiers enseignements', Cahiers Agricoles 25: 1-6.

Traoré, B. 2010. 'Processus de décentralisation en Côte d'Ivoire: Quelles stratégies de planification des activités des Conseils Généraux pour un développement local participatif reussie? Cas de Conseil Général Boundiali en Côte d'Ivoire', Memoire Master Analyse Economique et Développement Local, Université d'Auvergne (Marseille), <www.memoireonline.com/10/12/ 6318/m_Processus-de-decentralisation-en-Cte-d-Ivoire-quelles-strategies-de-planification-des-activiteo.html>, accessed 25.8.2015.

Varlet, F. et al. 2014. 'Etude d'impact social du volet d'appui à la mise en oeuvre de la loi sur le foncier rural du PARFACI'. République de Côte d'Ivoire, Ministère de l'Agriculture, Direction du Foncier Rural, CECAF International and Grain Côte d'Ivoire, Abidjan.

Zalo, L.D. 2006. 'Présentation de l'avancement actuel de la mise en oeuvre de la loi relative au domaine funcier rural: The current state of implementation of the 1998 invoirian law on rural land'. Report of the Directeur du Foncier Rural et du Cadastre Rural, Min. de l'Agriculture, Côte d'Ivoire, Montpellier: Colloque international 'Les frontières de la question foncière'. 